Vol. 28, No. 2 Agustus (2021), 117 - 123

P-ISSN : 0854-641X \& E-ISSN : 2407-7607, Diterbitkan Universitas Tadulako

\title{
PENGARUH RIZOBAKTERI PENGHASIL INDOLE-3-ACETIC ACID TERHADAP PERKECAMBAHAN BIJI TANAMAN PADI (Oryza Sativa L.)
}

\section{Effect of Indole 3-Acetic Acid Producing Rhizobacteria on Rice Seed (Oryza sativa L.) Germination}

\author{
Sutrisno ${ }^{1)}$ \\ ${ }^{1)}$ Program Studi Pendidikan Biologi, Fakultas Sains dan Teknologi, Universitas Islam \\ Negeri Walisongo Semarang \\ Email: sutrisno@walisongo.ac.id
}

Diterima: 15 Maret 2021, Revisi : 28 Juni 2021, Diterbitkan: Augustus 2021 https://doi.org/10.22487/agrolandnasional.v28i2.780

\begin{abstract}
Indole-3-Acetic Acid (IAA)-producing rhizobacteria is potential to be used as a biostimulant agent for rice plants to support sustainable agriculture. This study aimed to analyze the effect of IAA-producing rhizobacteria on rice (Oryza sativa L.) germination. The isolates of IAAproducing rhizobacteria used in this study were isolated previously with code KP2, KP6, KP9 and KP14. IR64 rice seeds were superficially sterilized using 5\% NaOCl solution. The seeds were then soaked in the isolate suspension and germinated in a sterile petri dish. The results were analyzed using one-way analysis of variance (ANOVA) method with further test using Duncan's multiple range test (DMRT). The highest germination percentage was $98.67 \pm 1.15 \%$ found under the KP6 isolate treatment while the greatest shoot length of $5.76 \pm 0.77 \mathrm{~cm}$ found under the KP2 isolate treatment. In the two treatments the shoot lengths of seedlings were significantly higher than that of the control. The highest root length was $9.49 \pm 0.41 \mathrm{~cm}$ under KP9 isolate treatment. The total lengths of seedlings and the vigor index of all treatments were significantly higher than those of the control with the highest values were $9.48 \pm 0.33 \mathrm{~cm}$ and $935 \pm 74$, respectively, found in the KP2 treatment. The conclusion of this study was that the IAA-producing rhizobacteria isolates in this study had a significant positive effect on rice germination and on the parameters of total length and vigor index of rice seedlings.
\end{abstract}

Keywords: Indole-3-Acetic Acid, Germination, Rhizobacteria, and Rice.

\begin{abstract}
ABSTRAK
Rizobakteri penghasil Indole-3-Acetic Acid (IAA) berpotensi digunakan sebagai agen biostimulan tanaman padi untuk mendukung pertanian berkelanjutan. Penelitian ini bertujuan untuk menganalisis pengaruh rizobakteri penghasil IAA terhadap perkecambahan tanaman padi (Oryza sativa L.). Isolat rizobakteri penghasil IAA yang digunakan dalam penelitian ini telah diisolasi sebelumnya dengan kode KP2, KP6, KP9 dan KP14. Biji padi IR64 disterilisasi permukaannya dengan menggunakan larutan $\mathrm{NaOCl} 5 \%$. Biji kemudian direndam dalam suspensi isolat dan
\end{abstract}


dikecambahkan dalam petri dish steril. Analisis hasil penelitian dilakukan dengan menggunakan metode one-way analysis of variance (ANOVA) dan uji lanjut yaitu duncan's multiple range test (DMRT). Hasil penelitian menunjukkan bahwa prosentase perkecambahan tertinggi adalah kelompok perlakuan KP6 yaitu 98,67 $\pm 1,15 \%$. Perlakuan dengan isolat KP2 memiliki pengaruh terbesar terhadap panjang tunas yaitu 5,76 $\pm 0,77 \mathrm{~cm}$. Panjang tunas kecambah dengan perlakuan KP2 dan KP6 berbeda nyata terhadap kontrol. Ukuran panjang akar tertinggi adalah 9,49 $\pm 0,41 \mathrm{~cm}$ dengan perlakuan isolat KP9. Panjang total kecambah dan indeks vigor pada semua perlakuan berbeda nyata dibandingkan kontrol dengan nilai tertinggi berturut-turut yaitu 9,48 $\pm 0,33 \mathrm{~cm}$ dan $935 \pm 74$ pada kelompok perlakuan KP2. Kesimpulan penelitian ini adalah bahwa isolat rizobakteri penghasil IAA pada penelitian ini berpengaruh positif secara signifikan terhadap perkecambahan tanaman padi pada parameter panjang total dan indeks vigor kecambah padi.

\section{Kata Kunci : Rizobakteri, Indole-3-acetic acid, Perkecambahan, dan Padi.}

\section{PENDAHULUAN}

Perubahan iklim berdampak pada berbagai masalah lingkungan termasuk penurunan kesuburan tanah sawah. Perubahan iklim dapat menyebabkan penurunan kadar nutrien dalam tanah yang tersedia bagi tanaman serta mempengaruhi dinamika patogen dan hama tanaman sehingga memungkinkan munculnya patogen dan hama jenis baru (Karmakar et al., 2016; Peace, 2020). Hal ini diperburuk dengan adanya peningkatan penggunaan pupuk, pestisida dan bahan kimia anorganik lain untuk memacu hasil panen. Penggunaan produk-produk tersebut dalam jangka panjang menyebabkan permasalahan pertanian. Bahan kimia anorganik memiliki dampak negatif karena dapat menyebabkan pengasaman tanah, eutrofikasi air, dan degradasi ekosistem (Gu et al., 2012).

Peningkatan hasil panen dengan pendekatan yang ramah lingkungan menjadi solusi alternatif untuk mendukung pertanian yang berkelanjutan. Pemanfaatan rizobakteri sebagai agen biostimulan yaitu pemacu pertumbuhan tanaman menjadi semakin menarik perhatian karena tidak menggunakan bahan anorganik sehingga berpotensi untuk digunakan dalam pertanian yang berkelanjutan. Rizobakteri tersebut dikenal dengan plant growth-promoting rhizobacteria (PGPR) yang merupakan bakteri yang hidup di area tanah rizosfer dengan peran sebagai pemacu pertumbuhan tanaman serta pelindung dari berbagai cekaman (Timmusk, 2017). PGPR memiliki berbagai mekanisme dalam mendukung pertumbuhan tanaman diantaranya adalah fiksasi nitrogen (Lin et al., 2012), pelarutan fosfat anorganik dan mineralisasi fosfat organic (Zaheer et al., 2019), produksi siderofor, 1-amino-cyclopropane-1 -carboxylate (ACC) deaminase dan hydrogen cyanate (Sulochana et al., 2014), sebagai agen kontrol biologis pathogen tumbuhan dan hama dengan mensintesis antibiotik maupun senyawa fungisida (Sun et al., 2017; Etesami et al., 2017), serta produksi berbagai fitohormon termasuk indole-3-acetic acid (IAA), sitokinin, dan giberelin (Matsuda et al., 2018; Cappellari et al., 2019).

Berbagai penelitian sebelumnya telah menunjukkan bahwa inokulasi PGPR ke tanaman merupakan metode efektif untuk memacu pertumbuhan tanaman dan hasil panen. Diantara penelitian tersebut menunjukkan adanya peningkatan pertumbuhan kecambah dan hasil panen padi setelah diberi perlakuan dengan bakteri Enterobacter cloacae (Suprapta et al., 2014). Penelitian lain oleh Sapsirisopa et al. (2009) juga menunjukkan bahwa perendaman biji padi dengan suspensi Bacillus megaterium A12ag mampu meningkatkan perkecambahan biji dan hasil panen padi pada cekaman salinitas. Inokulasi tanaman kapas dengan Azotobacter chroococcum berpengaruh positif terhadap pertumbuhan tanaman dan menurunkan penggunaan pupuk nitrogen hingga 50\% (Romero-perdomo et al., 2017).

Karakter utama untuk mengidentifikasi PGPR yang mampu meningkatkan pertumbuhan tanaman adalah kemampuan menghasilkan IAA (Wahyudi et al., 2011). Sebagian besar 
bakteri rizosfer mampu menghasilkan IAA. Tingkat kandungan auksin dalam tanaman dipengaruhi oleh IAA dari bakteri sehingga dapat menjadi optimal dan secara langsung mampu meningkatkan pertumbuhan tanaman (Iqbal et al., 2017). Efek fitostimulator yang dimiliki oleh IAA dari bakteri meningkatkan pertumbuhan tanaman dengan cara memacu perkembangan akar sehingga mampu menyerap air dan nutrient dengan lebih baik karena rasio luas dan volume akar meningkat (Ahmed \& Hasnain, 2010). Pengujian strain bakteri rizosfer penghasil IAA perlu dilakukan sehingga diperoleh strain yang berpotensi untuk digunakan sebagai agen biostimulan yang mampu mendukung pertumbuhan tanaman padi. Penelitian ini bertujuan untuk menganalisis pengaruh isolat bakteri rizosfer penghasil IAA terhadap perkecambahan biji padi.

\section{METODE PENELITIAN}

Penelitian ini dilakukan pada bulan Januari 2021 di laboratorium Jurusan Biologi Universitas Islam Negeri Walisongo Semarang. Bahan yang digunakan dalam penelitian ini adalah 4 isolat terpilih bakteri rizosfer penghasil IAA yang sudah diisolasi sebelumnya, biji padi (Oryza sativa L.) varietas IR64, media Nutrient Agar (NA), akuades steril dan larutan $\mathrm{NaOCl} 5 \%$. Persiapan inoculum dilakukan dengan menggunakan metode dari Saengsanga (2018) dengan modifikasi. Inokulum dibuat dengan melakukan pembiakan 4 isolat terpilih yaitu KP2, KP6, KP9 dan KP14 pada medium Nutrient Agar (NA) selama 48 jam. Sel-sel pada medium disuspensikan dengan cara menambahkan akuades steril ke medium dan dibuat suspense menggunakan drigalski. Suspensi bakteri diukur nilai optical density (OD) nya pada panjang gelombang $600 \mathrm{~nm}$ sehingga nilainya 1 .

Sterilisasi permukaan dilakukan dengan menggunakan metode dari Haque et al. (2020) dengan modifikasi. Biji padi disterilisasi permukaannya dengan merendamnya dalam larutan $\mathrm{NaOCl} 5 \%$ selama 2 menit kemudian dibilas dengan akuades steril sebanyak 3 kali.
Uji perkecambahan dilakukan dengan menggunakan metode dari Saengsanga (2018) dengan modifikasi. Biji padi yang telah disterilisasi permukaan direndam dalam suspensi bakteri selama 1 jam sehingga bakteri dapat mengkolonisasi biji padi. Biji juga direndam dalam akuades steril sebagai control tanpa inokulasi. Biji yang digunakan berjumlah 50 per ulangan dengan jumlah ulangan sebanyak 3 kali untuk masingmasing perlakuan dan kontrol. Biji kemudian dikecambahkan dalam petri dish dan direndam dengan akuades steril. Pemanjangan akar dan tunas diukur setelah 7 hari. Indeks vigor kecambah dihitung dengan menggunakan rumus : Indeks vigor kecambah $=\%$ germinasi $\mathrm{x}$ (panjang akar + panjang tunas) (Jegathambigai et al., 2009).

Hasil penelitian dianalisis untuk mengetahui beda nyata data perlakuan relatif terhadap kontrol dengan menggunakan metode one-way analysis of variance (ANOVA) dan uji lanjut yaitu duncan's multiple range test (DMRT). Analisis ini menggunakan software SPSS versi 25. Nilai $p<0,05$ menunjukkan bahwa data tersebut berbeda nyata.

\section{HASIL DAN PEMBAHASAN}

Indole-3-acetic acid (IAA) merupakan molekul yang berperan penting dalam interaksi antara mikroba dan tanaman serta mampu meningkatkan pertumbuhan tanaman secara langsung (Matsuda et al., 2018). IAA juga berperan dalam tahap awal perkecambahan biji pada banyak spesies tanaman (Pieruzzi et al. 2011). Beberapa genus rizobakteri asal tanaman padi yang telah dilaporkan memiliki aktivitas memacu pertumbuhan tanaman diantaranya adalah Pseudomonas spp. (Lavakush \& Verna, 2012), Bacillus megaterium A12ag, B. licheniformis B2r (Sapsirisopa et al., 2009), Alcaligenes dan Ochrobactrum (Bal et al., 2013). Pada penelitian ini sebanyak 4 isolat bakteri rizosfer penghasil IAA yang telah diisolasi sebelumnya yaitu KP2, KP6, KP9 dan KP14 digunakan untuk diujikan pengaruhnya 
terhadap perkecambahan biji tanaman padi. Beberapa parameter proses perkecambahan yang diukur adalah prosentase perkecambahan, panjang tunas dan akar semaian padi, dan indeks vigor perkecambahan. Hasil penelitian menunjukkan bahwa presentase perkecambahan perlakuan lebih tinggi dibandingkan dengan kontrol namun secara statistik tidak berbeda nyata (Gambar 1).

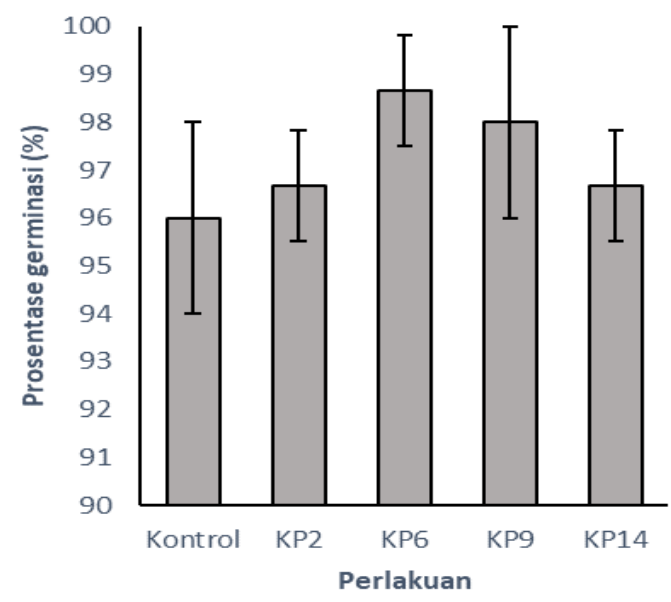

Gambar 1. Prosentase Perkecambahan.

Perlakuan dengan isolat KP6 memiliki prosentase perkecambahan tertinggi sedangkan KP2 dan KP14 memiliki pengaruh yang sama terhadap prosentase perkecambahan padi. Seluruh isolat terpilih juga mendukung pertumbuhan kecambah padi dimana tunas dan akar padi dengan perlakuan memiliki panjang yang lebih dibandingkan dengan kontrol (Gambar 2).

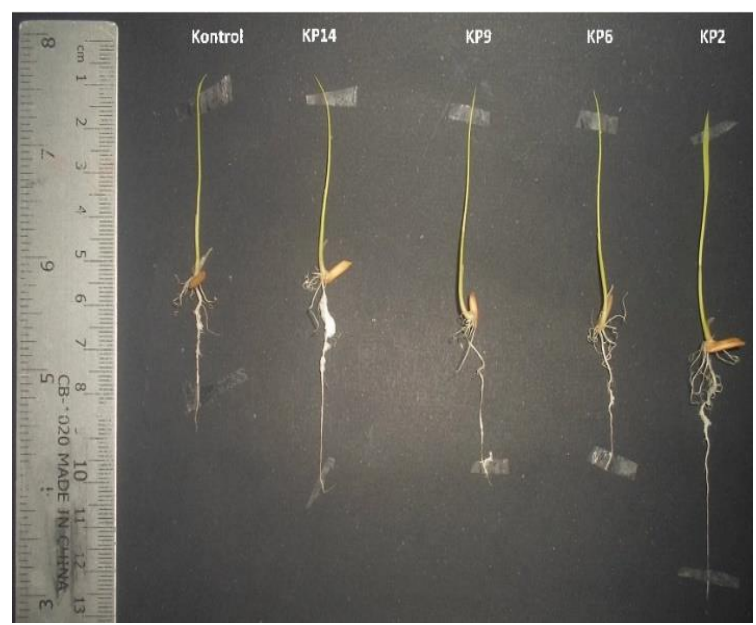

Gambar 2. Panjang Kecambah Padi Setelah Perlakuan.
Panjang tunas tertinggi adalah 5,76 $\pm 0,77 \mathrm{~cm}$ dengan perlakuan isolate $\mathrm{KP} 2$ (Gambar 3). Isolat ini mampu meningkatkan panjang tunas sebesar $26.69 \%$ dibandingkan kontrol. Penelitian oleh Mohite (2013) menunjukkan bahwa IAA yang dihasilkan oleh bakteri rizosfer mampu meningkatkan tinggi tanaman, akar tanaman serta kandungan klorofil secara signifikan jika dibandingkan dengan kontrol. Perlakuan dengan isolat KP14 mampu memacu pertumbuhan akar dengan panjang tertinggi yaitu $4,11 \pm 0,75 \mathrm{~cm}$ dimana peningkatannya sebesar 29.89\% dibandingkan dengan kontrol. Walaupun demikian, secara statistik panjang akar pada perlakuan tidak berbeda nyata dengan kontrol.

Sistem perakaran yang lebih panjang meningkatkan kemampuan tanaman untuk memperoleh air dan nutrisi seperti nitrogen yang cenderung berada pada lapisan tanah yang lebih dalam (Judd et al., 2015). IAA juga meningkatkan jumlah rambut akar dan akar lateral sehingga memperluas permukaan akar untuk penyerapan air dan nutrisi (Saikia et al., 2018).

Berbagai proses dalam perkembangan akar dan pertumbuhan tanaman dikendalikan oleh IAA. Tingkat konsentrasi IAA memiliki pengaruh yang berbeda terhadap perkembangan akar tanaman. Pada konsentrasi rendah, IAA mampu menstimulasi pemanjangan akar primer, walaupun demikian dalam konsentrasi yang tinggi IAA menyebabkan penurunan panjang akar primer akan tetapi juga mampu menstimulasi pembentukan akar lateral dan rambut akar (Vacheron et al., 2013).

Panjang total kecambah tertinggi dimiliki oleh kelompok perlakuan dengan isolat KP2 yaitu sebesar 9,48 $\pm 0,33 \mathrm{~cm}$ dengan peningkatan panjang sebesar $19.06 \%$ dibandingkan dengan kontrol. Panjang total pada semua jenis perlakuan secara statistik berbeda nyata dengan kontrol sehingga perlakuan ini berpengaruh positif secara signifikan terhadap panjang total kecambah padi. 


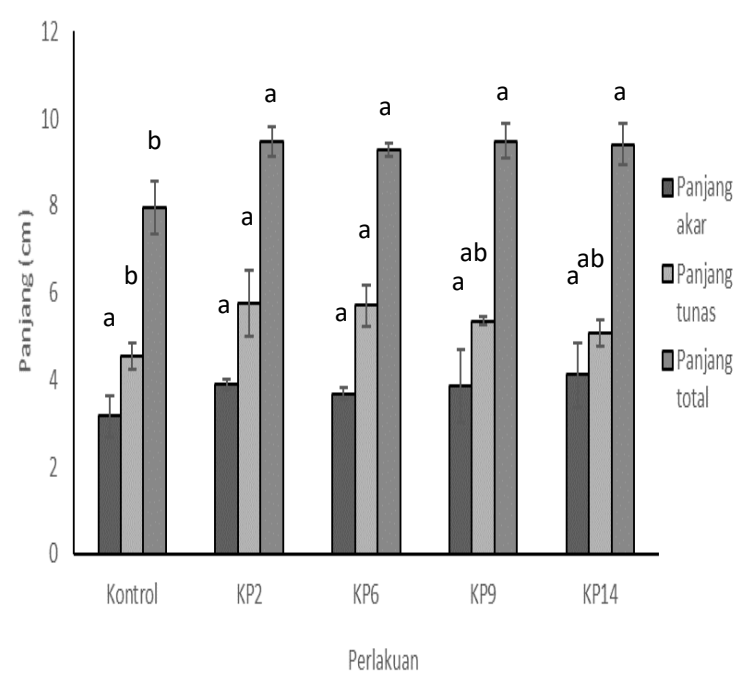

Gambar 3. Panjang akar, tunas dan total setelah perlakuan. Nilai dengan huruf yang berbeda menunjukkan perbedaan nyata berdasarkan uji statistik DMRT $(\mathrm{p}<0.05)$.

Vigor kecambah merupakan nilai kuantitatif yang menggambarkan kemampuan biji dalam berkecambah dan tumbuh menjadi semaian (Mohammad, 2014). Seluruh isolat pada penelitian ini memiliki pengaruh positif secara signifikan terhadap nilai indeks vigor (Gambar 4). Perlakuan dengan isolat KP2 menghasilkan nilai indeks vigor tertinggi yaitu $935 \pm 74$ dengan peningkatan sebesar $26.38 \%$ dibandingkan dengan kontrol.

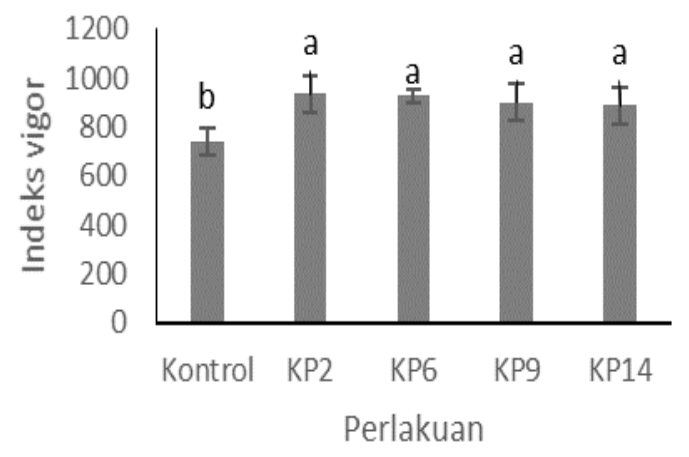

Gambar 4. Indeks vigor perkecambahan padi setelah perlakuan. Nilai dengan huruf yang berbeda menunjukkan perbedaan nyata berdasarkan uji DMRT ( $<$ $0,05)$.
Hasil penelitian ini sesuai dengan penelitian sebelumnya yang mununjukkan bahwa isolat bakteri Plant Growth Promoting Rhizobacteria (PGPR) penghasil IAA mampu meningkatkan indeks vigor kecambah padi secara signifikan dibandingkan dengan kontrol (Saengsanga, 2018). Nilai indeks vigor ditentukan oleh prosentase perkecambahan biji, panjang tunas serta akar kecambah padi. Parameter perkecambahan tersebut pada kelompok perlakuan memiliki nilai yang relatif tinggi dibandingkan dengan kontrol sehingga meningkatkan nilai indeks vigor kecambah padi. Hasil penelitian ini menunjukkan bahwa isolat bakteri rizosfer penghasil IAA berpengaruh positif secara siginifikan terhadap perkecambahan biji padi pada parameter panjang total dan indeks vigor kecambah padi sehingga berpotensi untuk digunakan sebagai agen biostimulan untuk memacu perkecambahan biji tanaman padi.

\section{KESIMPULAN}

Isolat rizobakteri penghasil IAA yang digunakan dalam penelitian ini berpengaruh positif secara signifikan terhadap perkecambahan biji tanaman padi pada parameter panjang total dan indeks vigor kecambah padi.

\section{DAFTAR PUSTAKA}

Ahmed, A., Hasnain, S. 2010. Auxin-producing Bacillus sp.: auxin quantification and effect on the growth of Solanum tuberosum. Pure and Applied Chemistry. 82(1) : 313-319.

Bal, H.B., Nayak, L., Das, S., Adhya, T.K. 2013. Isolation of ACC deaminase producing PGPR from rice rhizosphere and evaluating their plant growth promoting activity under salt stress. Plant Soil.

Cappellari LD, Santoro MV, Schmidt A, Gershenzon J, Banchio E. 2019. Inductionof essential oil production in Mentha $x$ piperita by plant growth 
promotingbacteria was correlated with an increase in jasmonate and salicylate levelsand a higher density of glandular trichomes. Plant Physiol Bioch.141:142-53.

Etesami, H., Emami, S., Alikhani, H.A. 2017. Potassium solubilizing bacteria (KSB): mechanisms, promotion of plant growth, and future prospects a review. JSoil Sci Plant Nut. 17(4):897-911.

Gu, B.J., Ge, Y., Ren, Y., Xu, B., Luo, W.D., Jiang, H., Gu, B.H., Chang J. 2012. Atmospheric reactive nitrogen in China: sources, recent trends, and damage costs. Environ Sci Technol. 46 (17): 9420-9427.

Haque, M.M., Mosharaf, M.K., Khatun, M., Haque, M.A., Biswas, M.S., Islam, M.S., Islam, M.M., Shozib, H.B., Miah, M.M.U., Molla, A.H., Siddiquee, M.A. 2020. Biofilm Producing Rhizobacteria With Multiple Plant Growth-Promoting Traits Promote Growth of Tomato Under Water-Deficit Stress. Front. Microbiol. 11: 1-25.

Iqbal, M., Wagi, S., Ahmed, A. 2017. Phyllospheric bacterial treatments improve growth in Helianthus annuus L. RADS Journal of Biological Research and Applied Sciences. 9(1) : 2521-8573.

Jegathambigai, V., Wijeratnam, R.S.W., Wijesundera, R.L.C. 2009. Trichoderma as a seed treatment to control Helminthosporium leaf spot disease of Chrysalidocarpus lutescens. World J. Agric. Sci. 5: 720-728.

Judd, L.A., Jackson, B.E., Fonteno, W.C. 2015. Advancements in root growthmeasurement technologies and observation capabilities for containergrown plants. Plants 4(3):369-392.

Karmakar, R., Das, I., Dutta, D., Rakshit, A. 2016. Potential effects of climate change on soil properties: a review. Sci. Intl. 4: 51-73.
Lavakush, J.Y., Verna, P. 2012. Isolation and characterization of effective plant growth promoting rhizobacteria from rice rhizosphere of Indian soil. Asian J. Biol. Sci.

Lin L, Li Z, Hu C, Zhang X, Chang S, Yang L, An Q. Plant growth-promotingnitrogenfixing Enterobacteria are in association with sugarcane plantsgrowing in Guangxi, China. Microbes Environ. 2012;27(4):391-8.13.

Matsuda, R., Handayani, M.L., Sasaki, H., Takechi, K., Takano, H., Takio, S. 2018. Production of indoleacetic acid by strains of the epiphytic bacteria Neptunomonas spp. isolated from the red alga Pyropia yezoensis and the seagrass Zostera marina. Archives of Microbiology. 200(2):255-265.

Mohammad, Y. 2014. Enhancement of seed germination and seedling vigor of wheat (Triticum aestivum L.) following PGPR treatments. Scholars Journal of Agriculture and Veterinary Sciences. 1 (3) : 121-124

Mohite, B. 2013. Isolation and characterization of indole acetic acid (IAA) producing bacteria from rhizospheric soil and its effect on plant growth. Journal of Soil Sciences and Plant Nutrition 13: 638649.

Peace, N. 2020. Impact of Climate Change on Insects, Pest, Diseases and Animal Biodiversity. Int J Environ Sci Nat Res. 23(5): 151-153.

Pieruzzi, F.P., Dias, L.L.C., Balbuena, T.S., Santa-Catarina, C., dos Santos, A.L.W., Floh, E.I.S. 2011. Polyamines, IAA and ABA during germination in two recalcitrant seeds: Araucaria angustifolia (Gymnosperm) and Ocotea odorifera (Angiosperm). Ann Bot. 108:337 345 .

Romero-Perdomo, F., Abril, J., Camelo, M., Moreno-Galván, A., Pastrana, I., RojasTapias, D., Bonilla, R. 2017. 
Azotobacter chroococcum as a potentially useful bacterial biofertilizer for cotton (Gossypium hirsutum): Effect in reducing $\mathrm{N}$ fertilization. Rev Argent Microbiol. 49(4): 377-383.

Saengsanga, T. 2018. Isolation and Characterization of Indigenous Plant Growth Promoting Rhizobacteria and Their Effects on Growth at the Early Stage of Thai Jasmine Rice (Oryza sativa L. KDML105). Arabian Journal for Science and Engineering. 43:33593369.

Saikia, J., Sarma, R. K., Dhandia, R., Yadav, A., Bharali, R., Gupta, V. K., et al. 2018. Alleviation of drought stress in pulse crops with ACC deaminase producing rhizobacteria isolated from acidic soil of northeast India. Sci. Rep. 8:3560.

Sapsirisopa, S., Chookietwattana, K., Maneewan, K., Khaengkhan, P. 2009. Effect of salt-tolerant Bacillus inoculum on rice KDML 105 cultivated in saline soil. As. J. Food Ag Ind. 6974.

Sulochana, M.B., Jayachandra, S.Y., Kumar, S.A., Parameshwar, A., Reddy, K.M., Dayanand, A. 2014. Siderophore as a potential plant growth-promoting agent produced by Pseudomonas aeruginosa JAS-25. Appl Biochem Biotech. 174(1): 297-308

Sun, G., Yao, T., Feng, C., Chen, L., Li, J., Wang, L. 2017. Identification and biocontrol potential of antagonistic bacteria strains against Sclerotinia sclerotiorum andtheir growth-promoting effects on Brassica napus. Biol Control. 104: 35-43.

Suprapta, D.N., Maulina, N.M.I., Khalimi, K. 2014. Effectiveness of Enterobacter cloacae to promote the growth and increase the yield of rice. J. Biol. Agric. Health. 4: 44-50.

Timmusk, S. 2017. Perspectives and challenges of microbial application for crop improvement. Front. Plant Sci. 8 (49).

Vacheron, J., Desbrosses, G., Bouffaud, M.L., Touraine, B., Moënne-Loccoz, Y., Muller, D., et al. 2013. Plant growthpromoting rhizobacteria and root system functioning. Front. Plant Sci. 4:356.

Wahyudi, A.T., Astuti, R.P., Widyawati, A., Meryandini, A., \& Nawangsih, A.A. 2011. Characterization of Bacillus sp. strains isolated from rhizosphere of soybean plants for their use as potential plant growth for promoting rhizobacteria. J Microbiol Antimicrobiol. 3: 34-40.

Zaheer, A., Malik, A., Sher, A., Qaisrani, M.M., Mehmood, A., Khan, S.U., Ashraf, M.U., Mirza, Z., Karim, S., Rasool, M. 2019. Isolation, characterization, and effect of phosphate-zinc-solubilizing bacterial strains on chickpea (Cicer arietinum L.) growth. Saudi J Biol Sci. 26(5): 1061-1067. 